\title{
A Key Role for gp130 Expressed on Peripheral Sensory Nerves in Pathological Pain
}

\author{
Manfred Andratsch, ${ }^{1}$ Norbert Mair, ${ }^{1}$ Cristina E. Constantin, ${ }^{1}$ Nadja Scherbakov, ${ }^{1}$ Camilla Benetti, ${ }^{1}$ Serena Quarta, ${ }^{1}$ \\ Christian Vogl, ${ }^{1}$ Claudia A. Sailer, ${ }^{1}$ Nurcan Üceyler, ${ }^{2}$ Johannes Brockhaus, ${ }^{3}$ Rudolf Martini, ${ }^{2}$ Claudia Sommer, ${ }^{2}$ \\ Hanns Ulrich Zeilhofer, ${ }^{3}$ Werner Müller, ${ }^{4}$ Rohini Kuner, ${ }^{5}$ John B. Davis, ${ }^{6}$ Stefan Rose-John, ${ }^{7}$ and Michaela Kress ${ }^{1}$ \\ ${ }^{1}$ Department of Physiology and Medical Physics, Division of Physiology, Innsbruck Medical University, A-6020 Innsbruck, Austria, ${ }^{2}$ Department of \\ Neurology, University of Würzburg, 97080 Würzburg, Germany, ${ }^{3}$ Institute of Pharmacology and Toxicology, University of Zürich, Switzerland and Institute \\ of Pharmaceutical Sciences, Swiss Federal Institute of Technology, 8057 Zürich, Switzerland, ${ }^{4}$ Faculty of Life Science, University of Manchester, M13 9PL \\ Manchester, United Kingdom, ${ }^{5}$ Institute for Pharmacology, University of Heidelberg, Im Neuenheimer Feld 364, D-69120 Heidelberg, Germany, \\ ${ }^{6}$ Discovery Technology Group, Research and Development, GlaxoSmithKline, CM19 5AW Harlow, Essex, United Kingdom, and 7 Institute of \\ Biochemistry, Christian-Albrechts-University, D-24098 Kiel, Germany
}

Interleukin-6 (IL-6) is a key mediator of inflammation. Inhibitors of IL-6 or of its signal transducing receptor gp130 constitute a novel class of anti-inflammatory drugs, which raise great hopes for improved treatments of painful inflammatory diseases such as rheumatoid arthritis. IL-6 and gp130 may enhance pain not only indirectly through their proinflammatory actions but also through a direct action on nociceptors (i.e., on neurons activated by painful stimuli). We found indeed that the IL-6/gp130 ligand-receptor complex induced heat hypersensitivity both in vitro and in vivo. This process was mediated by activation of PKC- $\delta$ via Gab1/2/PI $\mathrm{K}^{\mathrm{K}}$ and subsequent regulation of TRPV1, a member of the transient receptor potential (TRP) family of ion channels. To assess the relevance of this direct pain promoting effect of IL-6, we generated conditional knock-out mice, which lack gp130 specifically in nociceptors, and tested them in models of inflammatory and tumor-induced pain. These mice showed significantly reduced levels of inflammatory and tumor-induced pain but no changes in immune reactions or tumor growth. Our results uncover the significance of gp 130 expressed in peripheral pain sensing neurons in the pathophysiology of major clinical pain disorders and suggest their use as novel pain relieving agents in inflammatory and tumor pain.

\section{Introduction}

Pain management in conditions of chronic inflammation, such as rheumatoid arthritis (RA), remains a major clinical challenge. A large body of preclinical studies has been dedicated toward deciphering the pathophysiological sequelae of events occurring in immune cells during chronic inflammation. However, from the perspective of understanding chronic pain arising in these states, it is also important to understand and address bilateral interactions between immune cells and sensory nerves. Locally released cytokines are a key class of molecules which are particularly relevant in this context. Several lines of evidence show that cytokines play a key role in the pathophysiology of inflammation. A variety of key cytokines, e.g., interleukin-6 (IL-6), IL-11, leukemia inhibitory factor (LIF), oncostatin M (OSM), ciliary neurotrophic factor (CNTF), and cardiotropin-1 (CT-1), use the signal

Received April 16, 2009; revised July 31, 2009; accepted Aug. 19, 2009.

This work was supported by the Austrian Fond zur Förderung der wissenschaftlichen Forschung (P18444), Tiroler Wissenschaftsfond (UNI-0404/408), and the Wilhelm Sander-Stiftung (AZ1996.058.3) to M.K., and by the Deutsche Forschungsgemeinschaft Germany in SFB415 (project B5) and SFB654 (project (5) and within the Cluster of Excellence "Inflammation at Interfaces" to S.R.J. We thank M. Doblander and I. Lanz for expert technical assistance and G. Gstraunthaler and E. Feifel for general support.

Correspondence should be addressed to Dr. Michaela Kress, Division of Physiology, Department of Physiology and Medical Physics, Innsbruck Medical University, Fritz-Pregl-Strasse 3, A-6020 Innsbruck, Austria. E-mail: michaela.kress@i-med.ac.at.

DOI:10.1523/JNEUROSCI.1822-09.2009

Copyright $\odot 2009$ Society for Neuroscience $\quad$ 0270-6474/09/2913473-11\$15.00/0 transducer glycoprotein 130 (gp130) for signaling onto mast cells, macrophages, and other types of immune cells (Yoshida et al., 1996; Betz et al., 1998).

Of these, the pleiotropic cytokine IL-6 is particularly worth noting because its levels in healthy individuals are very low, but dramatically elevated in painful inflammatory conditions (Kiefer et al., 2001; Smith et al., 2001). In rats, a direct injection of IL-6 causes hypersensitivity to thermal and mechanical stimuli (Poole et al., 1995; Oka et al., 1995; DeLeo et al., 1996; Brenn et al., 2007). IL-6 complexes with membrane-bound or soluble IL-6 receptor, IL-6R, to activate cells expressing the signal transducer glycoprotein gp130 (Taga et al., 1989; Rose-John and Heinrich, 1994). Interestingly, most cells are devoid of membrane-bound IL-6R and are thus unresponsive to the cytokine IL-6. Such cells, however, can still react to IL-6 complexed with a soluble form of the IL-6R (sIL-6R) to activate gp130, a pathway called "transsignaling" (Rose-John and Heinrich, 1994). Interestingly, the sIL-6R is generated by apoptotic neutrophils during inflammatory states (Chalaris et al., 2007). In addition to immune and myeloid cells, gp130 is also expressed in rat sensory neurons (Oprée and Kress, 2000; Gardiner et al., 2002; Obreja et al., 2002a, 2005). However, the functional role of gp130 expressed on sensory nerves is not well understood. Furthermore, the signaling events downstream of gp130 in sensory nerves have not been explored, nor is it known how these may potentially impact on 
key nociceptive molecules, such as ion-channels involved in pain transduction.

We hypothesized that gp130 expressed on sensory nerve may be functionally linked to pathological pain. To specifically delineate the functional role of cytokine signaling via gp130 in sensory neurons, we used a conditional gene targeting approach in mice based on selective deletion of gp 130 from peripheral sensory neurons, leaving its expression in other cells intact. Our results suggest that gp130 expressed in sensory nerves not only mediates chronic inflammatory pain, but also contributes significantly to complex interactions between immune cells, tumor cells, and nerves in the context of cancer-evoked pain. Moreover, we identify IL- 6 activating gp 130 , Gab1/Gab2, $\mathrm{PI}_{3} \mathrm{~K}$, and PKC- $\delta$ and regulating TRPV1 as a key mechanism linking cytokine release to sensitization of pain-sensing nerves.

\section{Materials and Methods}

Genetically modified mice. Mice homozygous for the floxed allele of the mouse Il6st gene $\left(g p 130^{f l / f l}\right)$, which encodes the interleukin-6 signal transducer (Il6st, henceforth gp130) have been described previously (Betz et al., 1998). gp130 fl/fl mice were cross-bred with SNS-Cre mice (Agarwal et al., 2004) to obtain homozygous SNS-Cre gp130 fl/fl (SNS$g p 130^{-/-}$) and $g p 130^{f l / f l}$ mice (control littermates; the recombinase is homo- or heterozygous). All mice were genotyped using mouse genomic tail DNA with sense primer 5'-TGGCTTGAGCCTCAGCTTGGCTAG-3' and antisense primer 5'-TGAACAGTCACCATGTACATCTGTACGC-3 to detect the floxed gp130 allele, and sense primer 5'-GAAAGCAGCCATGTCCAATTTACTGACCGTAC-3' and antisense primer 5'-GCGCGCCTGAAGATATAGAAGA-3' to detect SNS-Cre transgene expression. SNS-Cre mice, SNS-gp130-/- mice and their corresponding littermates [wild-type (wt) and $g p 130^{f l / f l}$ mice, respectively] had the genetic background C57BL/6J. All mice were maintained under SPF conditions. Littermates were used in all experiments to control for background effects, and all animal use procedures were in accordance with ethical guidelines and animal welfare standards according to Austrian law. All behavioral measurements were done in awake, unrestrained, age-matched mice that were $>8$ weeks old by individuals who were blinded to the genotype of the mice being analyzed.

Southern blot. Genomic DNA from wild-type, $g p 130^{f l f l}$ and SNS$g p 130^{-1-}$ mice dorsal root ganglia (DRGs) was cleaved overnight at $37^{\circ} \mathrm{C}$ using EcoRI (Roche) in a $10 \times E c o$ RI buffer (Roche). DNA was separated on a $0.7 \%$ agarose gel containing ethidium bromide, and then blotted onto a nylon membrane (GeneScreen Plus, PerkinElmer Life Sciences) and placed on a UV transilluminator (UV-Stratalinker 2400, Stratagene). The gp130 genomic DNA probe was labeled with $\alpha$ - ${ }^{32} \mathrm{P}$-dCTP $(10.0$ $\mathrm{mCi} / \mathrm{ml}$, PerkinElmer Life Sciences) using the Megaprime DNA Labeling System (GE Healthcare). The membrane was prehybridized for $3 \mathrm{~h}$ at $50^{\circ} \mathrm{C}$ in a hybridization buffer containing $5 \times$ Denhardt's solution (bovine serum albumin (Sigma), polyvinylpyrrolidone (Sigma), Ficoll 400 (Sigma), $5 \times$ SSC, $1 \%(w / v)$ SDS (Sigma), and $100 \mu \mathrm{g} / \mathrm{ml}$ degraded salmon sperm DNA) (Sambrook and Russell, 2001). The probe was denatured, added to the hybridization buffer, and hybridized overnight at $50^{\circ} \mathrm{C}$. The membrane was then briefly washed in $2 \times$ SSC $/ 0.1 \%$ SDS at $50^{\circ} \mathrm{C}$ followed by $2 \times \mathrm{SSC} / 0.1 \% \mathrm{SDS} 2 \times 30 \mathrm{~min}$ at $50^{\circ} \mathrm{C}$ and then in $0.1 \times$ $\mathrm{SSC} / 0.1 \% \mathrm{SDS}$ for $10 \mathrm{~min}$ at $50^{\circ} \mathrm{C}$. Results were examined after exposure to X-ray film (GE Healthcare).

Qualitative and quantitative PCR. Qualitative PCR was performed, respectively, on RNA, cDNA, isolated from murine dorsal root ganglion (DRG) neurons, treated with TRI Reagent (Sigma), restricted with DNase I (Fermentas), and reverse transcribed with MuLV Reverse Transcriptase (Applied Biosystems). Specific PCR primers were picked according to NCBI referenced sequences. Primer Express Software, Version 3.0 (Applied Biosystems) was used to define primer base constitution, length, and melting temperatures. Oligonucleotides were purchased at MWG (Eurofins MWG Operon). The following sets of primers were used: set 1 , sense primer 5'-GATAACCTGCTCTGGGTGGA-3', antisense primer 5' ${ }^{\prime}$-TGGAGTTAAAATTGTG CCTTGG-3'; set 2, sense primer 5'-ACCAGATTCCTGTGGACGAC-3', antisense primer 5'TGACCACTGGGCAATATGAC-3'. The presence of the desired mutation in the resulting fragments of $400 \mathrm{bp}$ (wild type, $g p 130^{f l / f l}$ ) and $300 \mathrm{bp}$ (SNS-gp $130^{-1-}$ ) was confirmed by sequencing (Microsynth AG). The cycle protocol of the first PCR consists of $1 \mathrm{~min}$ at $94^{\circ} \mathrm{C}, 20$ three-step cycles of $30 \mathrm{~s}$ each at $94^{\circ} \mathrm{C}, 60 \mathrm{~s}$ each at $57^{\circ} \mathrm{C}$, and $120 \mathrm{~s}$ each at $72^{\circ} \mathrm{C}$, and a final extension at $72^{\circ} \mathrm{C}$ of $10 \mathrm{~min}$. The nested PCR was done as aforementioned; only the number of cycles was adjusted to 30 . For analysis of gene expression levels, respectively mRNA levels, total RNA was isolated from murine DRG neurons of untreated and treated animals immediately after preparation by using TRI Reagent (Sigma) according to the manufacturer's instructions. RNA was treated with DNase I (Fermentas). Reverse transcription to cDNA was performed using the GeneAmp RNA PCR Kit (Applied Biosystems). Each cDNA sample was analyzed for expression of gp130 by quantitative real-time PCR using the TaqMan 5' nuclease assays Mm01297292_m1 (gp130, exon boundary 16-17), Mm0129298_m1 (gp130, exon boundary 8-9) and Mm01352363_m1 (Succinate Dehydrogenase Subunit A, SDHA). In case of exon 15 (transmembrane region) a MGB probe (5'-TGTGCTTAGCCTTCC-3') and the primers $5^{\prime}$-GAAATAGAAGCC- $3^{\prime}$ and $5^{\prime}$-CCTGACAACCCTGCTGGGCGT-3' ${ }^{\prime}$, respectively (all Applied Biosystems), were used. Reactions were performed in a MicroAmp Fast Optical 96-Well Reaction Plate (Applied Biosystems) using the 7500 Fast Real-Time PCR System (Applied Biosystems) for thermal cycling and real-time fluorescence measurements. The PCR cycle protocol consisted of $10 \mathrm{~min}$ at $95^{\circ} \mathrm{C}$, and 40 two-step cycles of $15 \mathrm{~s}$ each at $95^{\circ} \mathrm{C}$ and of $1 \mathrm{~min}$ at $60^{\circ}$. Positive and negative controls were included in all the experiments and each sample was run in triplicate for each PCR. Threshold cycle $\left(\mathrm{C}_{\mathrm{T}}\right)$ values were recorded as a measure of initial template concentration. Relative fold changes in RNA levels were calculated by the $\Delta \Delta \mathrm{C}_{\mathrm{T}}$ method using SDHA as a reference standard. The range for the target, relative to a calibrator sample was calculated by $2^{-\Delta \Delta \mathrm{C}_{\mathrm{T}}}$.

Culture of primary sensory neurons. Lumbar DRGs with the cell bodies of primary afferents that project into the hindpaw were harvested from adult mice as previously published (Obreja et al., 2002b; Agarwal et al., 2007). After removal of the connective tissue, ganglia were incubated in Liberase Blendzyme 1 ( $9 \mathrm{mg} / 100 \mathrm{ml}$ DMEM, Roche) for $60 \mathrm{~min}$. After washing with PBS (PAA), $1 \times$ Trypsin-EDTA (Invitrogen) was added for $30 \mathrm{~min}$, and DRGs were washed TNB medium (Biochrom) containing L-glutamin (Invitrogen), penicillin G sodium, streptomycin sulfate (Invitrogen), and a Protein-Lipid-Komplex (Biochrom). The DRGs were triturated with a fire-polished Pasteur pipette and centrifuged through a $3.5 \%$ BSA gradient (Sigma). The sensory neurons were resuspended, plated on coverslips coated with polylysine/laminin (Sigma), and cultivated in supplemented TNB containing mNGF (Alomone Labs, $10 \mu \mathrm{g}$ / $100 \mathrm{ml} \mathrm{TNB}$-medium) at $37^{\circ} \mathrm{C}$ in $5 \% \mathrm{CO}_{2}$ for $24-36 \mathrm{~h}$.

Culture of tumor cells. Lung carcinoma cells (ETCC clone 1642, European Type Cell Culture Collection) were cultivated in DMEM with L-glutamine and $10 \%$ fetal bovine serum (FBS). Before injection, cells were counted, washed twice, and then resuspended in PBS $(25 \mu \mathrm{l})$. Mice were anesthetized with isofluorane (Baxter) and $7 \times 10^{5}$ lung carcinoma cells were injected subcutaneously in the plantar and dorsal side of the mouse hindpaw.

Immunocytochemistry and live cell labeling. DRG neurons were dissociated according to the protocol and plated on coverslips. After $24 \mathrm{~h}$ in culture, neurons were fixed with $4 \%$ PFA for $20 \mathrm{~min}$, permeabilized with $0.01 \%$ TX-100 (Sigma) for 2 min and blocked with blocking buffer (BB, 10\% goat serum in PBS) for $30 \mathrm{~min}$. Cells were incubated with primary antibodies diluted in $\mathrm{BB}$ (1:200) for $1 \mathrm{~h}$ at room temperature (RT), washed with PBS, and incubated with secondary antibodies (1:1000) for $30 \mathrm{~min}$ at RT. Nuclei were stained with $4^{\prime}, 6$-diamidino-2phenylindole (DAPI, 1:10,000 in PBS) and cells were embedded in Mowiol (Calbiochem). Cell counting was performed at least from triplicates of the experiments. For live cell labeling DRG neurons were incubated on ice with the primary antibody diluted in TNB medium (1:50) for $30 \mathrm{~min}$, washed with TNB medium for $10 \mathrm{~min}$ on ice, and incubated with the secondary antibody diluted in TNB medium (1: 1000). Subsequently cells were fixed with $4 \%$ PFA and proceeded to immunohistochemistry. 
Immunohistochemistry on frozen sections. DRGs were washed with PBS and fixed with $4 \%$ PFA for $20 \mathrm{~min}$. After $3 \times 10 \mathrm{~min}$ washing with PBS, ganglia were frozen in methylbutan. Sections $(12 \mu \mathrm{m})$ were cut with a Leica CM 1850 Cryomicrotome, permeabilized with $0.1 \%$ TX-100, and blocked with blocking buffer. Sections were incubated with primary antibodies overnight at $+4^{\circ} \mathrm{C}$ in a wet chamber. After washing in PBS, sections were incubated with the secondary antibodies, and embedded in Mowiol (Calbiochem). Indirect immune fluorescence was detected with a Zeiss Axiovert 200M microscope and analyzed with the MetaMorph Imaging Software Series 7.1 (Molecular Devices, Visitron Systems). The following antibodies were used: anti-gp130 (1:50, extracellular epitope, Neuromics); anti-Nav1.8 (1:200, was a generous gift from Prof. Dr. H. G. Knaus, Innsbruck, Austria) (see also supplemental Fig. 2, available at www.jneurosci.org as supplemental material) (Liu et al., 2006); antiCGRP (1:300, ImmunoStar), anti-Isolectin $\mathrm{IB}_{4}$ (1:1000, Invitrogen); Alexa Fluor 488 goat anti-rabbit $\operatorname{IgG}(1: 1000, \mathrm{H}+\mathrm{L})$, Alexa Fluor 594, donkey anti-goat IgG (1:1000, all Invitrogen).

Western blotting. Sensory neurons were plated on poly-L-lysine/ laminin-coated dishes, kept in culture for $24 \mathrm{~h}$, stimulated with $5 \mathrm{ng} / \mathrm{ml}$ HIL-6 for $10 \mathrm{~min}$ in extracellular solution (ECS), and harvested in freshly prepared ice-cold lysis RIPA-buffer (50 mm Tris- $\mathrm{HCl}, 150 \mathrm{~mm} \mathrm{NaCl}, 50$ mм NaF, 5 mм EDTA, 0.5\% Deoxycholic Acid, 0.1\% SDS, 1\% Nonidet $\mathrm{P}-40$, all Sigma). The phosphatase inhibitors sodium-orthovanadate $(200 \mu \mathrm{M})$ and $\beta$-glycerophosphate ( $40 \mathrm{~mm}$, both Sigma) were added to keep the proteins in phosphorylated state. A protease-inhibitor cocktail (Sigma) was used to protect proteins from proteolysis. SDS-PAGE was performed under standard denaturing conditions using $8.3 \times 7.3 \mathrm{~cm}$ handcast gels (Mini-PROTEAN, Bio-Rad Laboratories). Equal amounts of protein were loaded to each lane of $10 \%$ polyacrylamide gels. Spectra Multicolor Broad Range Protein Ladder (Fermentas) was used as a molecular weight standard. Gels were blotted immediately after electrophoresis onto polyvinylidene fluoride membrane (Hybond-P, GE Healthcare). For immunodetection, membranes were blocked for $1.5 \mathrm{~h}$ with $5 \%(\mathrm{w} / \mathrm{v})$ nonfat dry milk or 5\% (w/v) BSA and $0.1 \%(\mathrm{v} / \mathrm{v})$ Tween 20 in Tris-buffered saline, $\mathrm{pH} 7.6$, at room temperature, and processed according to the instructions of the manufacturers of the antibodies. The following antibodies were used: anti-tubulin (Sigma), anti-phosphoGab1(Tyr307), anti-phospho-Gab2(Tyr502), anti-phospho- $\mathrm{PI}_{3} \mathrm{~K}$ p85 (Tyr458)/p55 (Tyr199) (all Cell Signaling Technology), anti-Gab1 (H198), and anti-Gab2 (I-18) (both Santa Cruz Biotechnology). Visualization of blots was performed with enhanced chemiluminescence by using the ECLPlus Western Blotting Detection System (GE Healthcare).

Translocation of $P K C-\delta$. Cultured neurons were stimulated with 5 $\mathrm{ng} / \mathrm{ml} \mathrm{HIL-6}$ in ECS for $10 \mathrm{~min}$, fixed in 4\% PFA for $20 \mathrm{~min}$, permeabilized in $0.2 \%$ TX-100 for $5 \mathrm{~min}$, blocked with $10 \%$ NGS, and stained with anti-PKC $\delta$ (BD Transduction Laboratories). Images were obtained by a Zeiss Axiovert $200 \mathrm{M}$ laser confocal microscope LCM 510. To quantify the redistribution of PKC- $\delta$ after stimulation, line scan profiles of fluorescence intensities were recorded with the MetaMorph Imaging Series 7.1 Software (Visitron Systems). The total length of the profile along the diameter of the cell was set to $100 \%$, and fluorescence intensities of the profile between 0 and $10 \%$ and 90 and $100 \%$ were determined (periphery) together with intensities between 45 and $55 \%$ of the profile (center of cell). The translocation coefficient $(K)$ was calculated as ratio of the values determined for the average of the periphery divided by the value within the center of the cell as previously published (Rathee et al., 2002). $K=1$ if the enzyme is equally distributed throughout the cell, $K>1$ refers to predominant localization close to the plasma membrane, and $K<1$ represents a predominantly cytoplasmic localization.

Patch-clamp recordings. DRG neurons in culture were used for electrophysiology after $24 \mathrm{~h}$. Whole-cell ionic currents were recorded from isolated neurons in the whole-cell configuration of the patch-clamp technique as previously published (Obreja et al., 2002b, 2005). ECS contained (in mM): $150 \mathrm{NaCl}, 5 \mathrm{KCl}, 0.1 \mathrm{CaCl}_{2}, 1 \mathrm{MgCl}_{2}$ (all Sigma), 10 glucose, and 10 HEPES (Merck), at pH 7.3 adjusted with $\mathrm{NaOH}$ (Merck). Calcium was reduced to $0.1 \mathrm{~mm}$ to avoid desensitization of capsaicin-induced currents. Borosilicate glass pipettes (Science Products) pulled with a horizontal puller (Sutter Instruments Company) were filled with internal solution (ICS) (in mM): $148 \mathrm{KCl}, 2 \mathrm{MgCl}_{2}, 2 \mathrm{Na}-\mathrm{ATP}, 0.1 \mathrm{CaCl}_{2}, 1$ EGTA (all Sigma), and 10 HEPES (Merck), at pH 7.3 adjusted with $\mathrm{KOH}$ (Merck). After filling, electrode resistance was 4-5 M . Neurons were clamped at $-80 \mathrm{mV}$ holding potential. Currents were filtered at $2.9 \mathrm{kHz}$, sampled at $3 \mathrm{kHz}$, and recorded with an EPC 9 (HEKA) and the Pulse v8.74 software (HEKA). Experiments were performed at room temperature and only one neuron was tested per Petri dish. A seven barrel system with common outlet was used for fast drug administration and heat stimulation of single neurons (Dittert et al., 1998). Capsaicin-activated inward currents $\left(I_{\text {caps }}\right)$ were elicited by applying $0.3 \mu \mathrm{M}$ capsaicin (Sigma) for $10 \mathrm{~s}$ followed by a $2 \mathrm{~min}$ washout with control solution. This protocol was repeated 3 times before HIL-6 $(1 \mathrm{ng} / \mathrm{ml})$ was applied for 1 min immediately before capsaicin for conditioning stimulation. Recombinant interleukin-6 from mouse (IL-6, Sigma) was solved in PBS containing 10\% BSA. IL-6 (5 ng/ml) and BSA (vehicle; $0.1 \mathrm{mg} / \mathrm{ml}$ ), respectively, were used in the extracellular solution.

Skin-nerve preparation and single fiber recordings. An in vitro skin nerve preparation was used to investigate the properties of the afferent nerve fibers innervating the skin of the mouse dorsal hindpaw as previously published (Kress et al., 1992; Koltzenburg et al., 1997). Briefly, the preparation was superfused $(15 \mathrm{ml} / \mathrm{min})$ with an oxygen-saturated modified synthetic interstitial fluid solution containing (in $\mathrm{mm}$ ) $108 \mathrm{NaCl}, 3.48$ $\mathrm{KCl}, 3.5 \mathrm{MgSO}_{4}, 26 \mathrm{NaHCO}_{3}, 1.7 \mathrm{NaH}_{2} \mathrm{PO}_{4}, 2.0 \mathrm{CaCl}_{2}$, 9.6 sodium gluconate, 5.5 glucose, 7.6 sucrose at temperature of $31 \pm 1^{\circ} \mathrm{C}$, and $\mathrm{pH} 7.4 \pm$ 0.05 . Action potentials of single sensory neurons were recorded extracellulary from fine filaments dissected from the saphenous nerve, amplified (5000-fold), filtered (low pass $1 \mathrm{KHz}$, high pass $100 \mathrm{~Hz}$ ), visualized on oscilloscope, and stored on a PC-type computer with Spike/Spidi software package (Forster and Handwerker, 1990). The fibers were characterized as unmyelinated (C) according to their conduction velocity (c.v. $<1.4 \mathrm{~m} / \mathrm{s}$ ). The receptive field was identified by mechanical probing of the skin with a glass rod; standard heat stimuli linearly rising the intracutaneous temperature from $31 \pm 1^{\circ} \mathrm{C}$ to $47^{\circ} \mathrm{C}$ were applied. A fiber was considered heat sensitive if 3 or more action potentials were evoked during the stimulus. The heat threshold was defined as the temperature that elicited the third spike of the response. In tumor-injected mice electrophysiological recordings were performed 7-10 d after inoculation when a tumor mass had formed at the injection site.

Electron microscopy. SNS-gp130-/- and the corresponding $g p 130^{f l / f l}$ control mice were transcardially perfused with cacodylate buffer containing $2 \%$ freshly depolymerized paraformaldehyde and $2 \%$ glutardialdehyde, followed by femoral nerve dissection, osmification, and embedding in Spurr's medium as described previously (Carenini et al., 2001). Ultrathin sections ( $80 \mathrm{~nm}$ ) were contrasted with lead citrate and analyzed using a ProScan Slow Scan CCD (Proscan) camera mounted to a Leo $906 \mathrm{E}$ electron microscope (Zeiss) and corresponding software iTEM (Olympus).

Slice recordings. Spinal cord slices of $14-20$-d-old mice were obtained by a standard procedure. In short, the mice were anesthetized with isoflurane and decapitated, the spinal cord was microdissected in ice-cold ACSF (containing $125 \mathrm{~mm} \mathrm{NaCl}, 26 \mathrm{~mm} \mathrm{NaHCO} 3,1.25 \mathrm{~mm} \mathrm{NaH}_{2} \mathrm{PO}_{4}$, $2.5 \mathrm{~mm} \mathrm{KCl}, 2 \mathrm{mM} \mathrm{CaCl}_{2}, 1 \mathrm{~mm} \mathrm{MgCl}_{2}, 10 \mathrm{~mm}$ glucose), glued to a gelatin block, and frontal slices were obtained by a vibroslicer. Lumbar slices with intact dorsal rootlets were fixed in a recording chamber with a platinum grid and a bipolar stimulation electrode $(250 \mu \mathrm{m}$ pole distance) was placed on both sides of the rootlet. Synaptic currents of dorsal horn neurons (layer 2/3) in response to stimulation of the primary afferents with short pulses $(0.2 \mathrm{~ms}$ duration, pulse distance $12 \mathrm{~s})$ were recorded with an EPC10 and patch master software (HEKA) by use of patch pipettes filled with a K-gluconate-based internal solution $\left(\mathrm{Cl}^{-}\right.$reversal potential $-90 \mathrm{mV}$ ). The stimulation threshold was identified as the lowest voltage strength with a response probability $>50 \%$.

Behavioral testing. Standard testing procedures were used to quantify signs of pain-like behavior. The area tested was the plantar side of the hindpaw where the tumor cells were inoculated. Heat sensitivity was assessed using the Hargreaves test (Hargreaves et al., 1988). Paw withdrawal latency in response to an increasing heat stimulus was measured automatically (Ugo Basile) before and after cytokine injection or tumor cell injection at time points as indicated in figures. Instead of coinjecting 
IL-6 together with sIL-6R, the designer peptide hyper-IL-6 (HIL-6) was used to mimic the effects of the IL-6/sIL-6R complex (Fischer et al., 1997). Complete Freund's Adjuvant (CFA, 20 $\mu \mathrm{l}$, Sigma) was injected into the plantar site of the hindpaw in $g p 130^{f l f l}$ and SNS-gp130 13 mice, and changes in the mechanical and heat sensitivity were measured 6, 24, and 48 h after inoculation. At the end of the observation period, tumors were excised in toto, cleaned from connective tissue, and weighed immediately. For CCI of the right sciatic nerve, mice were anesthetized by intraperitoneal phenobarbital injection, and three ligatures (7-0 prolene) with a distance of $1 \mathrm{~mm}$ each were loosely tied around the nerve proximal to the trifurcation until a short flick of the hindpaw was observed.

Statistical analysis. For detailed statistical analysis the SigmaStat 3 program was used. Data are presented as mean \pm SEM and were analyzed using the Wilcoxon signed rank test, the paired $t$ test or one-way repeated-measures ANOVA for comparison between groups and test days, followed by a Student's $t$ test if not otherwise stated. Differences were considered statistically significant at $p<0.05$.

\section{Results}

Animals deficient for the ubiquitously expressed signal transducer IL-6 receptor $\beta$ subunit gp130 die after $12.5 \mathrm{~d}$ postconception or postnatally, depending on the genetic background (Yoshida et al., 1996; Kawasaki et al., 1997). Therefore, conditional knock-out mice lacking gp130 selectively in nociceptive neurons of the DRG were generated using the Cre recombinase loxP strategy and conditional removal of the transmembrane exon 15 (referred to henceforth as SNS-gp130-/- mice). This was achieved by mating homozygous mice carrying the loxP-flanked (floxed) $g p 130$ allele $\left(130^{f l / f l}\right.$ ) (Betz et al., 1998) with a mouse line expressing Cre recombinase under the transcriptional control of the nociceptor-specific $\mathrm{Na}_{\mathrm{v}} 1.8$ gene ( $S N S$-Cre). In SNS-Cre mice, gene recombination selectively occurs in $>90 \%$ of small size ( $\leq 28 \mu \mathrm{m})$ nociceptive sensory neurons, commenced at birth and does not affect gene expression in other regions (Agarwal et al., 2004). Deletion of $g p 130$ in DRG neurons was detected by Southern blot analysis on genomic DNA of mouse DRGs using a $g p 130$ specific probe and via quantitative PCR analysis (supplemental Fig. 1, available at www.jneurosci.org as supplemental material). To confirm that gp130 protein was absent from the cell membrane, live immune staining was performed with antibodies directed against the extracellular domain of gp130 and the $\mathrm{Na}_{\mathrm{v}} 1.8$ ion channel in neuron cultures obtained from $g p 130^{f l / f l}$ and SNS$g p 130^{-/-}$mice, which revealed that $>90 \%$ of the $\mathrm{Na}_{\mathrm{v}} 1.8$-positive neurons in SNS- $g p 130^{-/-}$mice did not show anti-gp130 immunoreactivity on their cell surface (Fig. 1A,B). Thus these three independent methods suggest an efficient recombination and deletion of functional gp130 in nociceptive neurons. In contrast, expression of gp130 remained intact in other tissues, including immune cells, in SNS-gp130-/- mice (data not shown).

No obvious developmental abnormalities occurred on loss of gp130 from sensory neurons. Since cytokine signaling via gp130 such as IL-6 or LIF are important survival factors and also regulate neuronal excitability (März et al., 1999; Schäfer et al., 1999; Brenn et al., 2007; Kawasaki et al., 2008), we assessed whether the two main classes of nociceptive neurons in the DRG, namely the peptidergic, CGRP-expressing $(\mathrm{CGRP}+)$ and the nonpeptidergic, Isolectin B4 binding (IB4+) nociceptors (Caterina and
Julius, 1999) were different from wild-type littermates. The morphology and the overall frequency of IB4 and CGRP + neuron populations were similar between wild-type and SNS-gp130 DRGs (Fig. $2 A, B$, ) suggesting that the lack of the gp130 signal transducer did not affect the morphology or general structural properties of sensory neurons. Electron microscopy revealed no pathological alterations in nonmyelinated nerve fibers of SNS$g p 130^{-/-}$mice (Fig. 2C,D). General morphology of the spinal dorsal horn and electrophysiological parameters of synaptic spinal transmission in the substantia gelatinosa were similar in both mouse strains (supplemental Fig. $3 A, B$, available at www. jneurosci.org as supplemental material). Overt motor or other behavioral deficits were not observed in the SNS-gp130 ${ }^{-/-}$mice compared with littermates.

Functional consequences of gp130 loss from sensory neurons No overt difference was observed regarding basal heat pain sensitivity in mice lacking neuronal gp130. Since IL-6 is found at high levels in inflamed tissue, we investigated SNS-gp130 mice in a model of inflammation-induced hyperalgesia. Subcutaneous inoculation of $20 \mu \mathrm{l}$ of CFA $(1 \mathrm{mg} / \mathrm{ml})$ into the plantar site of the hindpaw led to development of inflammation and hypersensitivity to noxious heat stimulation, both in $g p 130^{f l / f l}$ and SNS-gp130-1- mice within $6 \mathrm{~h}$ after injection (Fig. $3 \mathrm{~A}$ ). However, although the degree of swelling, which is an indication of inflammation, was very similar in both mouse strains (Fig. 3B), the heat hyperalgesia was significantly attenuated in SNS- $g p 130^{-1-}$ compared with $g p 130^{f l f l}$ mice $\left(p<0.001\right.$, ANOVA). In $g p 130^{f l f l}$ mice, inflammatory hyperalgesia fully developed within $6 \mathrm{~h}$ and remained at constant levels for up to $48 \mathrm{~h}$. In contrast, after an initial peak at $6 \mathrm{~h}, S N S-g p 130^{-1-}$ showed significant recovery from the hyperalgesic state, although inflammation persisted (Fig. 3A).

\section{Significance of neuronal gp130 for cancer pain}

In a novel model for cancer pain in mice, we have recently shown that on a subcutaneous injection of LL2 carcinoma cells into hindpaw, the tumor stroma shows signs of an inflammatory reaction and is densely invaded by macrophages, which are known to produce large amounts of cytokines when activated (Constantin et al., 2008). In this model, tumor growth is accompanied by sprouting of peptidergic nerve fibers into the tumor mass, pro- 


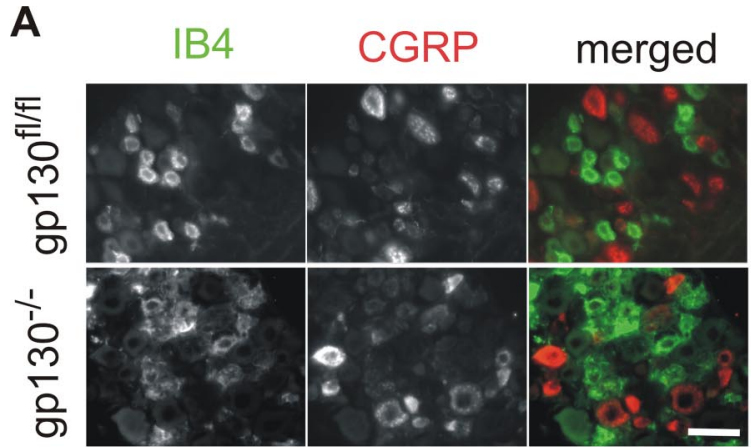

C

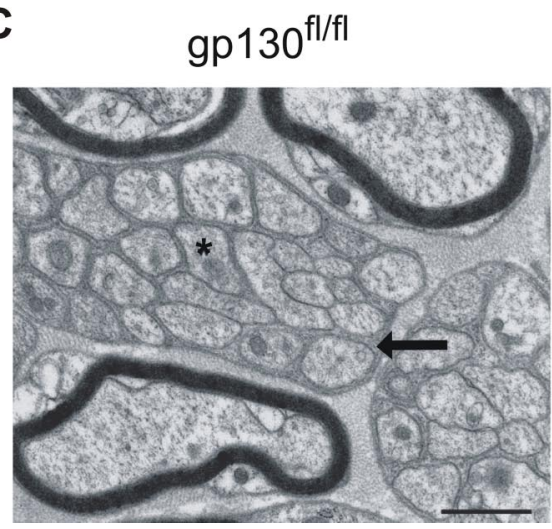

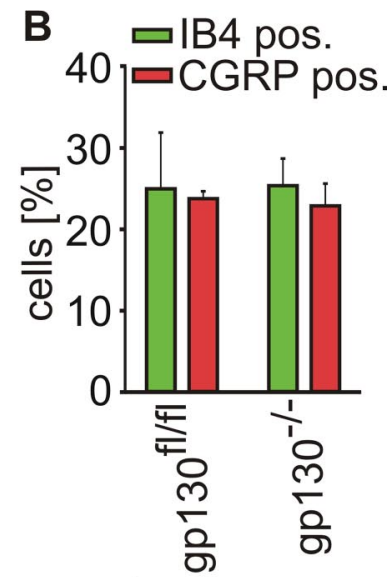

D

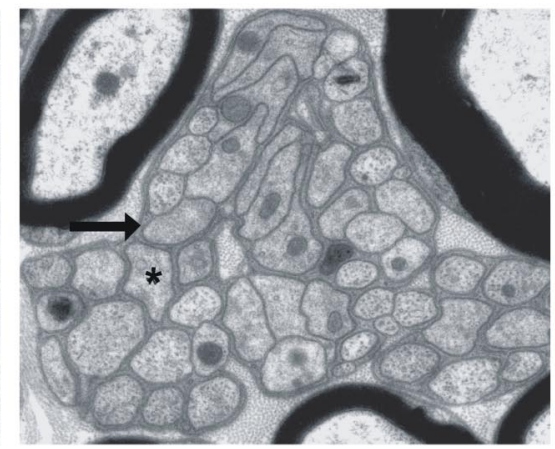

Figure 2. Normal morphology of sensory ganglia and peripheral nerve in SNS-gp $130^{-/-} . A, B$, Distributions of IB4 and CGRP immunoreactivity were similar in DRG sections obtained from $g p 130^{\mathrm{fl} / f}$ and SNS-gp $130^{-/-}$mice. Percentages of IB4- or CGRP-immunoreactive neurons in DRG sections were also comparable for the two mouse strains. This indicates that peptidergic and nonpeptidergic small-size neuron populations were in general normal in the SNS-gp $130^{-/-}$mice. All experiments were repeated in at least 3 animals. $C, D$, Electron microscopy on nonmyelinated nerve fibers of saphenous nerves of $g p 130^{f / f f l}$ control and SNS-gp $130^{-/-}$mice at the age of $4-6$ months. Asterisks demarcate nonmyelinated axons; arrows point to cytoplasmic processes of the nonmyelinating Schwann cells. Dark structures surrounding larger caliber axons are myelin sheaths. Note that there were no pathological alterations in the mutant nerves. corded from naive healthy mice $(p>$ 0.05; ANOVA (Fig. 3F). This suggests that gp130 expressed on nociceptive primary afferents plays an important role in the generation of tumor-induced heat hyperalgesia and directly regulates the sensitivity of painsensing neurons. No major contribution of gp130 was observed in a model of neuropathic pain, in which the development of heat hyperalgesia was delayed, but not prevented. This was likely due to lack of a major inflammatory component in this model (supplemental Fig. 4, available at www. jneurosci.org as supplemental material).

\section{Relevance of IL-6 for tumor-associated} pain and nociceptor sensitization

The above analyses suggest that gp130 expressed on sensory nerves plays a direct role in pathophysiological processes triggered by cytokines in sensory nerves. To study in depth which molecular events would functionally link cytokine-induced gp130 to nociceptive hypersensitivity, we turned to IL-6, a key cytokine implicated in pathological inflammatory disorders and pain. In the tumor material we also found expression of IL-6 mRNA, which was not detected in LL2 cell cultures before injection into the paw (Fig. $4 A$ ), suggesting an upregulation of IL- 6 expression in tumor cells or associated immune cells in vivo. Correspondingly, we found significant upregulation of IL- 6 protein levels in the tumor tissue compared with healthy control tissue (e.g., skeletal muscle) (Fig. 4B).

In most tissues, IL-6 requires a ligandbinding soluble receptor subunit (sIL-6R), gressive mechanical and heat hyperalgesia, and a significant sensitization of nociceptors in wt C57BL6J mice (Constantin et al., 2008). As the tumors grew, a progressive heat hyperalgesia was observed in $g p 130^{f l f l}$ mice $(p<0.001$, ANOVA, $n=23$ ) (Fig. $3 C)$. In $S N S-g p 130^{-1-}$ mice, heat hyperalgesia was significantly attenuated, and mild signs of heat hyperalgesia developed only in the very late stages after tumor induction (Fig. 3D). This beneficial effect was not due to a reduction of tumor growth or inflammation because tumor growth and paw swelling were similar in $g p 130^{f l f f l}$ and $S N S-g p 130^{-1-}$ mice (Fig. 3G).

\section{Neuronal gp130 required for tumor-associated nociceptor sensitization}

In wt C57BL6J mice, tumor-induced hyperalgesia is accompanied by a sensitization of heat-sensitive nociceptive fibers innervating the skin in the tumor area. We therefore hypothesized that activation of neuronal gp130 might be critical for the nociceptor sensitization process and performed single fiber recordings from unmyelinated nociceptive primary afferents in a skin-nerve in vitro preparation (Reeh, 1986; Koltzenburg et al., 1997). In vitro, heat-sensitive unmyelinated fibers from $g p 130^{f l f l}$ tumor mice exhibited higher mean discharge rates during heat stimuli compared with fibers from control mice without tumor $[4.53 \pm 1.00$ impulses (imp)/s versus $2.27 \pm 0.53 \mathrm{imp} / \mathrm{s} ; p<0.05$; ANOVA] (Fig. 3E). In SNS-gp130 ${ }^{-1-}$ mice with tumors, the mean heat response magnitudes were similar to those in nociceptors re- which complexes with the membrane-bound gp130 signaling subunit. A recent study by Chalaris et al. showed that neutrophils, which normally precede the incoming macrophages, are a major source of sIL-6R during inflammatory states (Chalaris et al., 2007). This suggests that both IL-6 and sIL-6R are present in the tumor tissue. A designer fusion peptide, HIL-6, has been shown to bind and activate gp130 and to mimic IL-6/sIL-6R effects in many tissues (Fischer et al., 1997). We used HIL-6 as a tool to investigate whether activation of gp130 affects pain behavior in mice. Injection of HIL-6 ( $1 \mu \mathrm{g}$ in 10 $\mu \mathrm{l})$ into the foot pad of a hindpaw in gp130 $1 /$ /fl mice led to a significant drop in paw withdrawal latencies (PWLs) to heat stimulation from $8.89 \pm 0.43 \mathrm{~s}$ before to $4.20 \pm 0.43 \mathrm{~s} 30 \mathrm{~min}$ after inoculation $(p<0.001$; ANOVA). PWL recovered to preinjection values within $24 \mathrm{~h}$ (Fig. 4C). Compared with $g p 130^{f l / f l}$ littermates, HIL-6-induced drop in paw withdrawal latencies was significantly attenuated in the nociceptor-specific SNS-gp130-/- mice (Fig. 4D), suggesting that a major part of HIL-6-induced heat hyperalgesia requires gp130 expressed in the membrane of nociceptor terminals or axons. Only a minor part of the sensitization was found to be independent of neuronal gp130, and could result potentially from a release of secondary inflammatory mediators from other gp130-expressing cell types, e.g., those cytokines which signal via gp130-independent receptors, such as the oncostatin M receptor (OSM-R) and the interleukin-27 receptor WSX-1 (Scheller et al., 2005). Based on the magnitude of changes observed in the above experiments, we propose that IL- 6 is one of the most important cytokines in this respect. Consistent with 

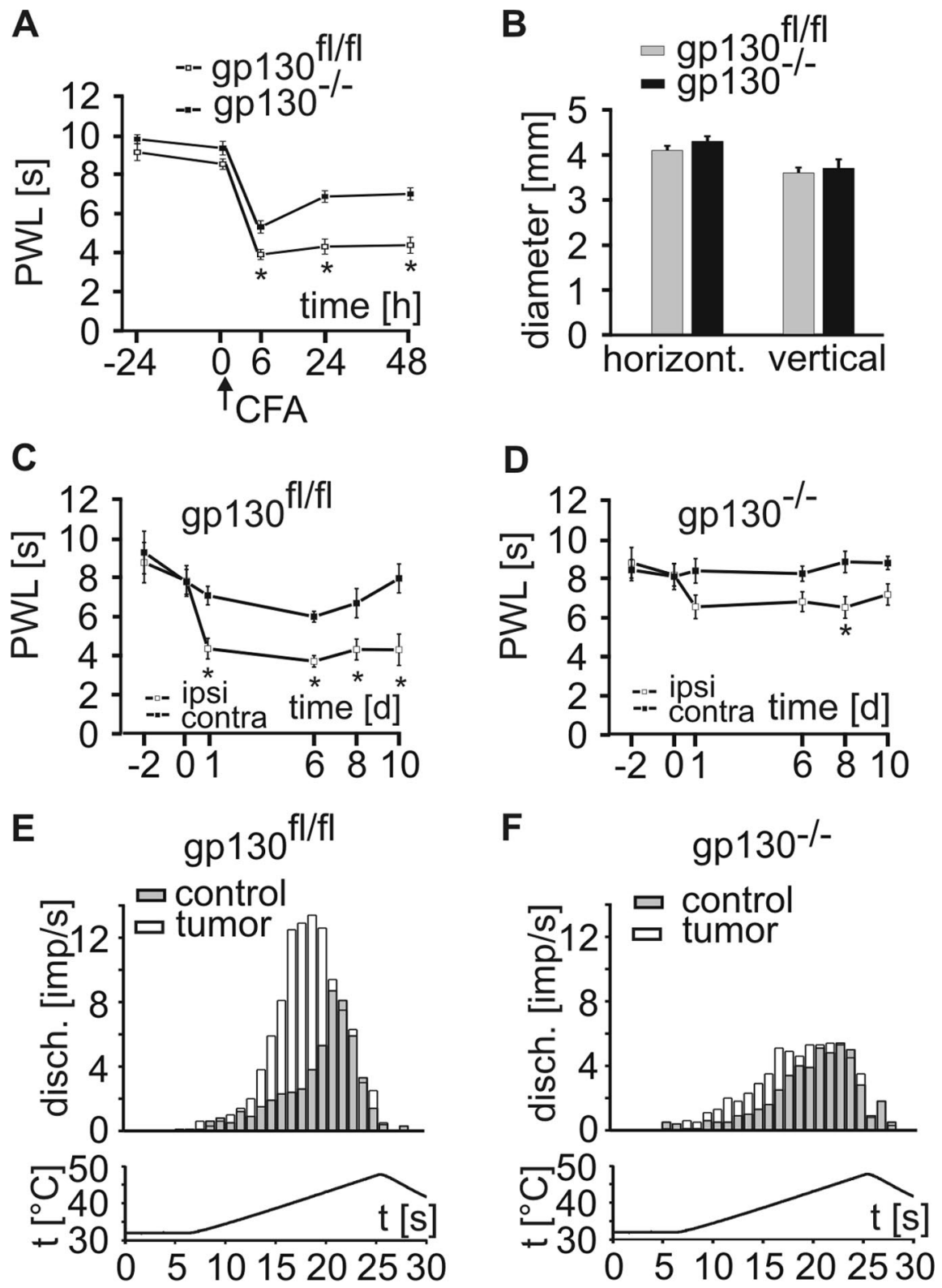

G

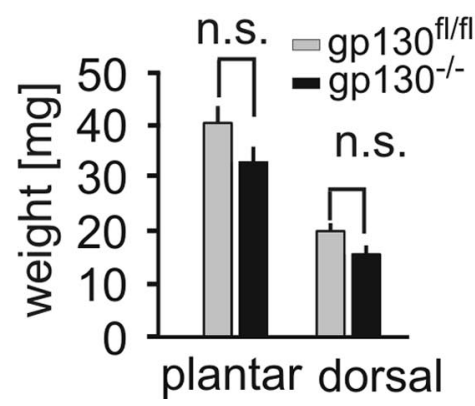

Figure 3. Heat hyperalgesia in pain models required neuronal gp130. $\boldsymbol{A}$, Changes in heat sensitivity following unilateral hindpaw injection of CFA in $g p 130^{f / f l}$ and SNS-gp $130^{-/-}$mice. Paw withdrawal latency in response to ramp heat stimuli applied to the inflamed area was significantly attenuated at all time points in SNS-gp130 ${ }^{-/-}$mice $(n=18)$ compared with $g p 130^{f / f l}$ $(n=17)$. Asterisks indicate significant differences ( $p<0.001$, ANOVA) between the two groups. $\boldsymbol{B}$, In contrast, no difference in the paw diameters was observed between strains, suggesting that an equal degree of CFA inflammation occurred despite the deletion of neuronal gp130. C, D, PWL in response to ramp-shaped heat stimuli applied to the plantar side of the hindpaw ipsilateral $(\square)$ and contralateral $(\square)$ to tumor in $g p 130^{f / f f l}(\boldsymbol{C}, n=23)$ and SNS-gp $130^{-/-}(\boldsymbol{D}, n=17)$ mice. After tumor induction in $g p 130^{f / f f}$ mice, paw withdrawal latency decreased significantly $(p<0.05$, ANOVA), starting from day 1 after injection and persisted over the $10 \mathrm{~d}$ of investigation. Mice with sensory neuron-specific deletion of gp 130 developed significant the above, pain sensitivity has been reported to be attenuated in mice lacking IL6 or in wild-type mice after neutralization of endogenous IL-6 (Ferreira et al., 1993; Xu et al., 1997; Murphy et al., 1999). Furthermore, we observed that other cytokine activators of gp130, such as leukemia inhibitory factor (LIF), neither induced heat hypersensitivity in vivo nor sensitized nociceptive neurons in vitro (supplemental Fig. 5, available at www.jneurosci.org as supplemental material).

Further evidence for a critical role for IL-6 in the phenotype observed in SNS$g p 130^{-/-}$mice was found in the following experiments. In the skin-nerve preparation, application of HIL- $6(1 \mathrm{ng} / \mathrm{ml})$ to the receptive field of unmyelinated heatsensitive fibers induced a significant augmentation of responses to a standard ramp-shaped heat stimulus in 64\% (7/11) of heat-sensitive C-fibers in $g p 130^{f l / f l}$ mice (Fig. 4E; mean discharge $2.01 \pm 0.42$ $\mathrm{imp} / \mathrm{s}$ before vs $4.17 \pm 0.72 \mathrm{imp} / \mathrm{s}$ after HIL-6; $p<0.01$; paired $t$ test). This sensitization occurred within $5 \mathrm{~min}$ after HIL-6 application and was accompanied by a significant shift of the activation threshold to a lower temperature $\left(38.0 \pm 1.8^{\circ} \mathrm{C}\right.$ before versus $34.3 \pm$ $0.9^{\circ} \mathrm{C} 5$ min after HIL-6; $p<0.05$ paired $t$ test). In contrast, none of the fibers recorded from SNS-gp130 13 mice responded to HIL- 6 with a potentiated heat response (Fig. $4 F ; n=7$; n.s.; Wilcoxon rank test). Together, the data suggest, that gp130 expressed in nociceptors is required for IL-6 to induce heat hypersensitivity in vivo and heat sensitization of nociceptors in vitro.

Finally, we performed electrophysiological studies in cultured neurons isolated from wild-type DRGs, which directly showed that HIL-6 sensitizes capsaicin-sensitive neurons to heat stimuli. In particular, we found a significant increase of heat-activated inward currents after conditioning stimulation with HIL-6 in isolated small diameter

heat hypersensitivity only on day 8 after tumor induction. Asterisks indicate significant differences $(p<0.001)$ between ipsilateral and contralateral paw. $\boldsymbol{E}, \boldsymbol{F}$, Discharge profiles of heat-sensitive C-fibers innervating the dorsal site of the hindpaw recorded in an in vitro skin-nerve preparation from gp130 ${ }^{f / f t}(\boldsymbol{E})$ and SNS-gp130-/- $(\boldsymbol{F})$ mice. Mean discharge rates in heat-sensitive (-fibers from $g p 130^{f / / f l}$ tumor mice $(n=8)$ were significantly higher compared with those from control (naive) mice $(\boldsymbol{E}, n=12, p<0.05$, ANOVA). Tumor induction in SNS-gp $130^{-1-}$ mice did not affect the discharge rates of the heat-sensitive fibers $(\boldsymbol{F}, p>0.05$, ANOVA). $\boldsymbol{G}$, Weights of plantar and dorsal tumors were similar in mutant and floxed mice (n.s., not significant). 
A

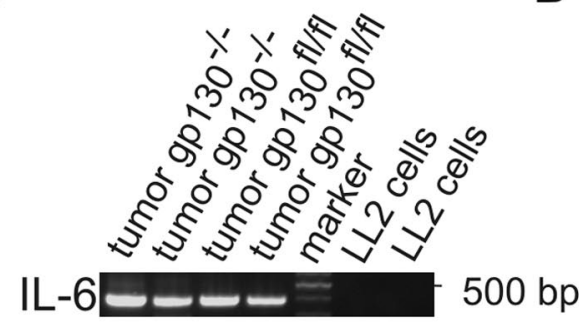

B
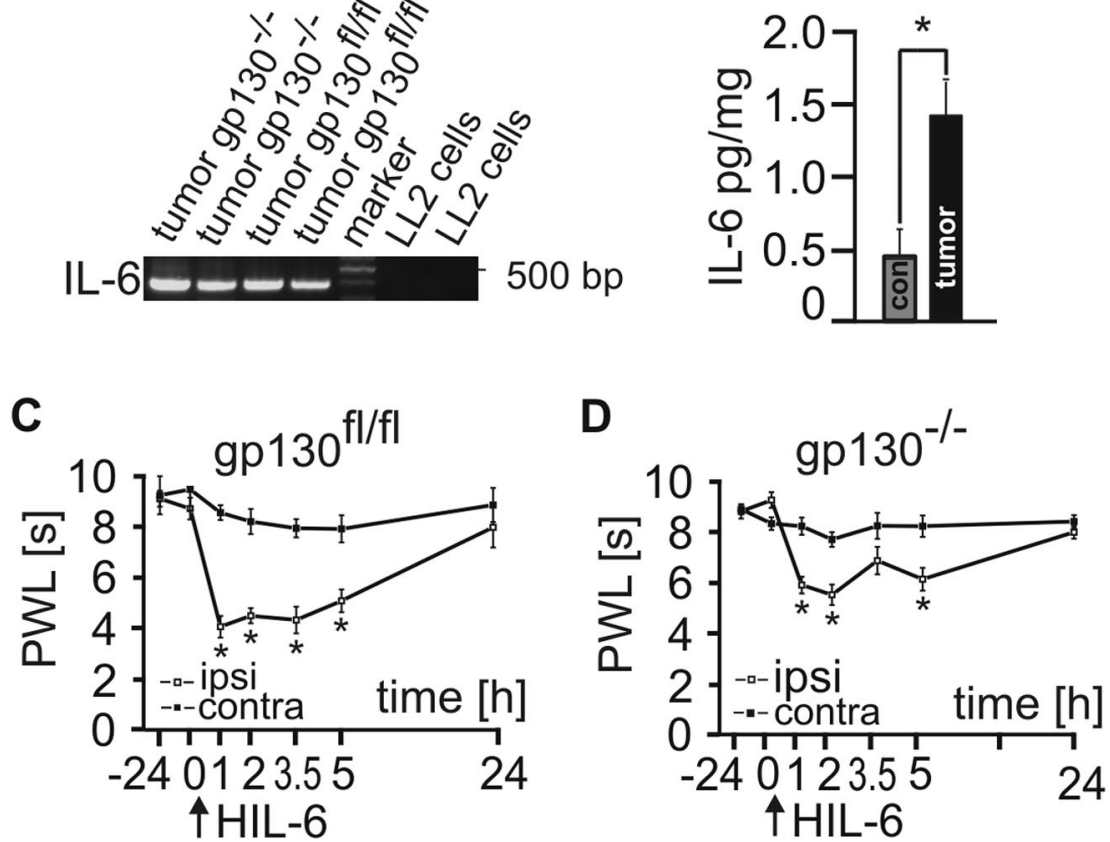

$\mathbf{E}$
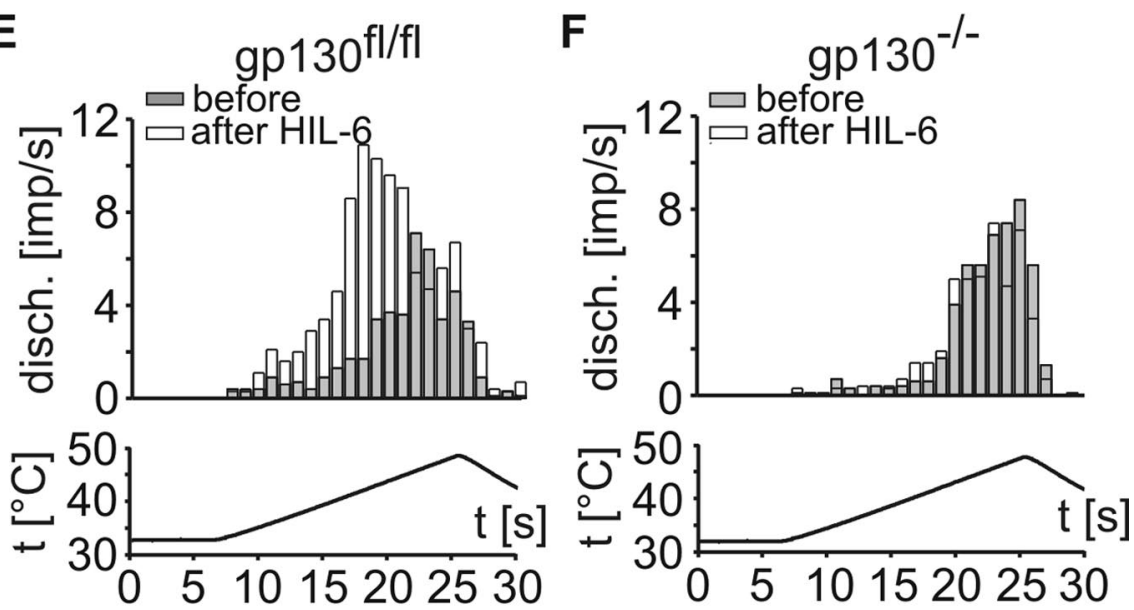

G

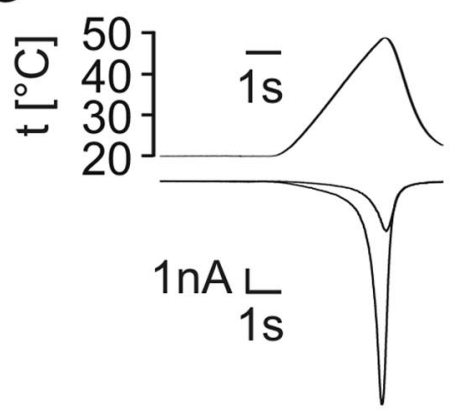

H

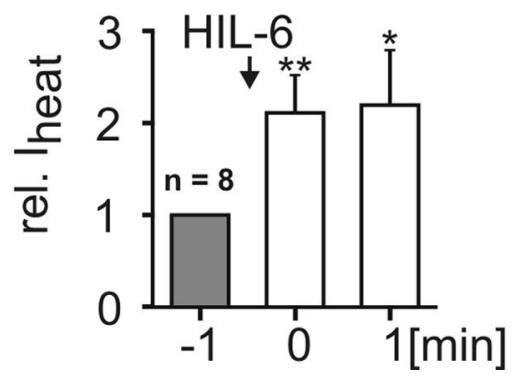

Figure 4. IL6-induced heat hyperalgesia and significance of neuronal gp130. $\boldsymbol{A}$, IL-6 mRNA was expressed in tumors of both mouse strains but absent in LL2 cell cultures; and $\boldsymbol{B}$, IL-6 levels (in pg cytokine/mg protein) were significantly higher in tumor homogenates (plantar and dorsal) compared with control tissue (muscle and spinal cord) isolated from 11 mice. C, $\mathbf{D}$, Intraplantar injection of HIL-6 $(1 \mu \mathrm{g}$ in $10 \mu \mathrm{l})$ in $g p 130^{\mathrm{fl} / \mathrm{fl}}(n=8)$ and SNS-gp $130^{-/-}$mice $(n=10)$ evoked a drop of PWL in response to heat stimulation. Asterisks indicate the data points at which a significant difference ( $p<0.001$, ANOVA) between the ipsilateral $(\square)$ and contralateral $(\square)$ side was observed. PWL decreased to significantly lower values in $g p 130^{f / f l}(n=8)$ compared with SNS-gp130 ${ }^{-/-}$mice $(p<0.01$, ANOVA, $n=10)$. $\boldsymbol{E}, \boldsymbol{F}$. Discharge profiles of heat-sensitive C-fibers before and after HIL-6 (1 $\mathrm{ng} / \mathrm{ml}$ ) application on the receptive fields in an in vitro skin-nerve preparation from $g p 130^{f / f l}(\boldsymbol{E})$ and SNS-gp130 ${ }^{-/-}(\boldsymbol{F})$ mice. HIL-6 application for 5 min induced a significant increase in the mean rate of discharge of the heat C-nociceptors from $\mathrm{gp} 130^{\mathrm{f} / \mathrm{f}}$

DRG neurons (Fig. 4G,H), which was accompanied by a shift of activation thresholds toward lower temperatures.

\section{IL-6-induced signaling in sensory neurons}

We then sought to clarify the major signaling components underlying the striking functional role we observed for gp 130 in pain modulation. The capsaicin- and heat-sensitive ion channel TRPV1, a member of the TRP (transient receptor potential) family of ion channels serves as molecular transducer at the nociceptive nerve terminals (Caterina et al., 1997; Scott and Zuker, 1998; Julius and Basbaum, 2001; Minke and Cook, 2002; Montell, 2005), and there is ample evidence that TRPV1 regulation by inflammatory mediators is essential for the generation of heat hyperalgesia (Davis et al., 2000; Chuang et al., 2001). We hypothesized that TRPV1 could be regulated by gp130 signaling. TRPV1 is activated not only by heat stimuli but also by capsaicin, the pungent ingredient of hot chili peppers, and in small-sized neurons, HIL-6 induced a fast and transient potentiation of capsaicinactivated ionic currents $\left(I_{\text {caps }}\right)$ from $1.04 \pm 0.34 \mathrm{nA}$ before to $1.82 \pm 0.07 \mathrm{nA}$ after HIL-6 (Fig. 5A; supplemental Fig. 6, available at www.jneurosci.org as supplemental material). A similar increase of $I_{\text {caps }}$ was also obtained after conditioning stimulation of gp $130^{\mathrm{fl} / \mathrm{fl}}$ neurons with recombinant IL-6 (Fig. 5B), suggesting that IL- 6 binding receptor $\alpha$ subunits are also expressed in the nociceptive cell membrane. This is in contrast to the rat in which the sensitizing effect of IL-6 requires soluble IL-6 receptor (Obreja et al., 2005). Expectedly, the conditioning effect of IL-6 was fully abrogated in neurons lacking the gp130 protein from SNSgp130 ${ }^{-/-}$mice (Fig. 5B). Using capsaicininduced excitatory inward currents as a read-out, we addressed the underlying signaling pathway and proposed a role of Gab1/Gab2, $\mathrm{PI}_{3} \mathrm{~K}$ and $\mathrm{PKC}-\delta$ (Heinrich et al., 2003). We performed Western blot experiments with phosphospecific antibodies, which revealed that adapter proteins Gab1, Gab2 (Nishida et al., 1999), and $\mathrm{PI}_{3} \mathrm{~K}$ are phosphorylated in DRG neurons after stimulation with HIL-6 (Fig. 5C). In

$\leftarrow$

$(\boldsymbol{E}, p<0.01$, paired $t$ test, $n=7)$. Heat-sensitive C-fibers from SNS-gp $130^{-/-}$mice were not affected by HIL-6 stimulation $(\boldsymbol{F}, p>0.05$, Wilcoxon rank test, $n=7) . \boldsymbol{G}, \boldsymbol{H}$, $I_{\text {heat }}$ was significantly facilitated after HIL-6 $(\boldsymbol{H})$, and the increase in peak current amplitudes was accompanied by a shift in activation threshold temperature $(\boldsymbol{G})$. 
the presence of wortmannin $(1 \mu \mathrm{M})$, a $\mathrm{PI}_{3} \mathrm{~K}$ inhibitor, HIL-6 no longer induced a sensitization of $I_{\text {caps }}$ (Fig. 5D) suggesting that $\mathrm{PI}_{3} \mathrm{~K}$ was involved in the signaling cascade downstream of gp 130 in nociceptive neurons. It is known that protein kinase $\mathrm{C}(\mathrm{PKC})$ can be recruited on $\mathrm{PI}_{3} \mathrm{~K}$ activation in SK-N-BE cells ( $\mathrm{Plo}$ et al., 2004) and translocation of PKC from a cytosolic to a membraneassociated location within the cell is a sensitive indicator of PKC activation. In rat DRG sensory neurons, both $\mathrm{PKC}-\delta$ and $\mathrm{PKC}-\varepsilon$ are clearly translocated to the surface membrane on treatment with the PKC activator phorbol-12-myristate-13acetate (PMA) (Cesare and McNaughton, 1996). Since PKC- $\delta$ has been associated with $\mathrm{PI}_{3} \mathrm{~K}$ activation, we investigated whether this isoform was translocated following exposure to HIL-6. In untreated neurons of both $g p 130^{f l f l}$ and $S N S-g p 130^{-/-}$mice, PKC- $\delta$ was distributed uniformly throughout the cytoplasm. Stimulation with HIL-6 caused an activation of $\mathrm{PKC}-\delta$, which was visible as redistribution from the cytosol to the cell membrane. In contrast, no migration of PKC- $\delta$ was observed in sensory neurons of mutant mice (Fig. $5 E, F$ ). In line with the translocation of PKC- $\delta$, both the nonselective PKC inhibitor BIM-1 (data not shown) and the PKC- $\delta$ inhibitor Rottlerin (Gschwendt et al., 1994) significantly reduced or abolished the HIL6-induced facilitation of $I_{\text {caps }}$ (Fig. 5G). Together, these data suggest a gp130mediated activation of PKC- $\delta$ via Gab1/ $2 / \mathrm{PI}_{3} \mathrm{~K}$, and consecutive regulation of heat and capsaicin activated ion currents.

The phenotypic alterations seen in SNS-gp130-/- (lack of heat hypersensitivity in pathological pain models) and the involvement of PKC prompted us to address the potential modulation of TRPV1 by gp130 signaling in sensory neurons. After HIL-6 injection, wild-

type mice reacted with a significant drop in PWL from $15.21 \pm$ $0.91 \mathrm{~s}$ before the injection to $5.10 \pm 0.77 \mathrm{~s}$ after $1 \mathrm{~h}(p<0.001$; Student's $t$-Test, $n=6$ ), which recovered to preinjection values within $24 \mathrm{~h}$. In TRPV1 ${ }^{-/-}$mice, the drop in PWL was significantly attenuated $(15.44 \pm 1.51 \mathrm{~s}$ before the injection vs $10.43 \pm$ $0.62 \mathrm{~s}$ after $1 \mathrm{~h}$ ) (Fig. $5 H$ ). One hour after HIL-6 injection wild-type littermates showed a significant drop in PWL in comparison with TRPV1 ${ }^{-/-}$mice $\left(5.10 \pm 0.77 \mathrm{~s}\right.$ in wt vs $10.43 \pm 0.62 \mathrm{sin} \mathrm{TRPV1} 1^{-/-}$; $p<0.001$; Mann-Whitney Rank Sum Test, $n=6$ ). These experiments suggest that TRPV1 plays a major role in HIL-6-induced heat hypersensitivity in vivo and revealed that sensitization of nociceptive neurons to heat was due to a regulation of TRPV1. This did not result from differences in TRPV1 expression patterns since mRNA analysis using quantitative PCR revealed that TRPV1 mRNA expression levels were similar in the mutant mouse and the wild type (data not shown).
B

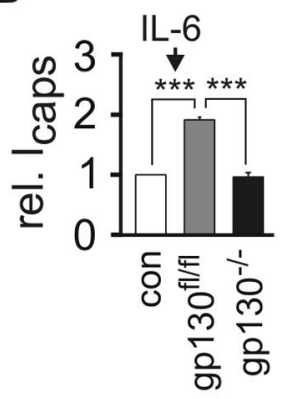

C

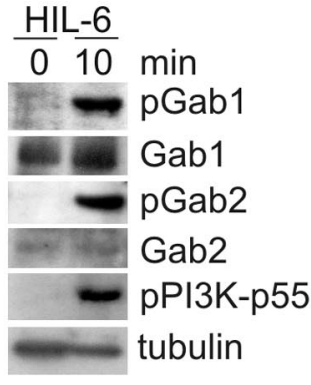

E
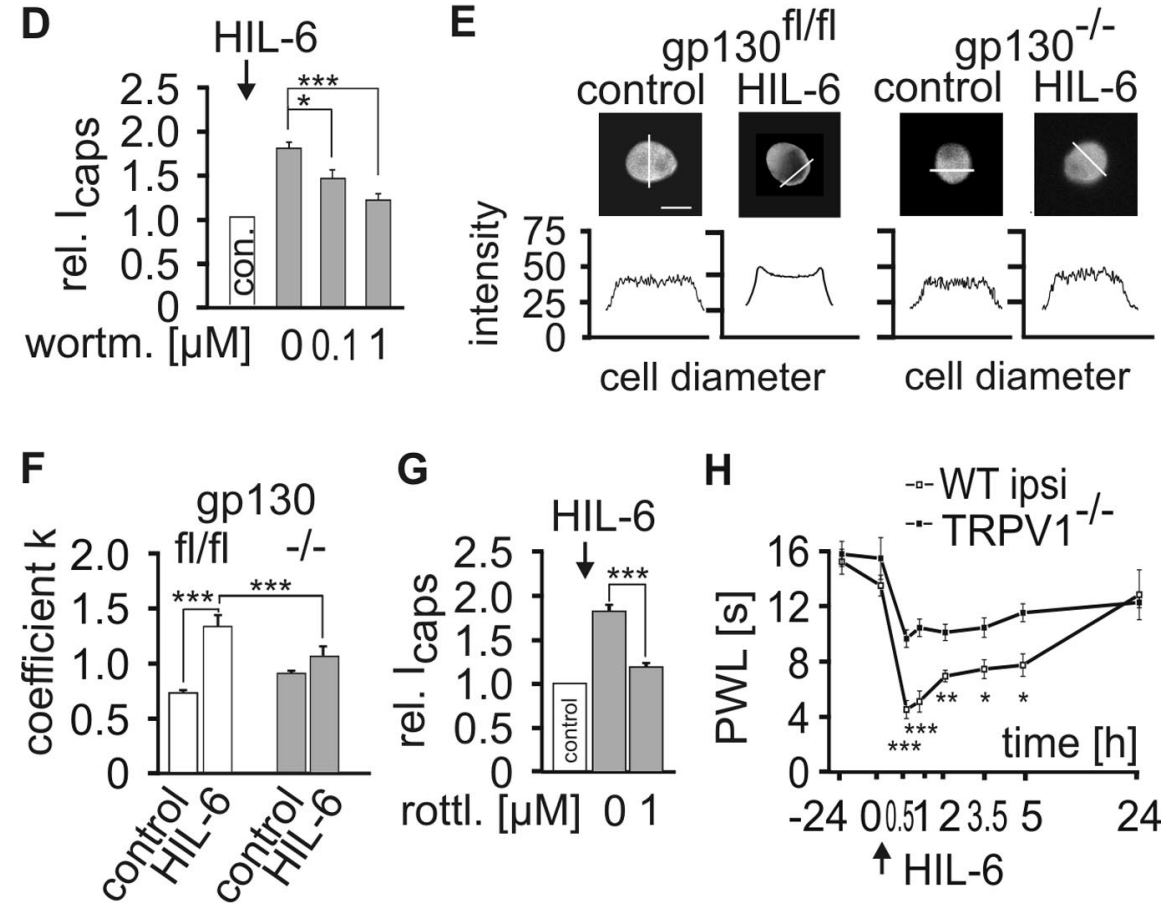

Figure 5. Downstream signaling of IL-6/gp130 via Gab1/2, $\mathrm{PI}_{3} \mathrm{~K}$ and PKC- $\delta . \boldsymbol{A}, \boldsymbol{B}$, Capsaicin-induced ionic currents were transiently and significantly facilitated by HIL-6. C, HIL-6 induced phosphorylation of the adapter proteins Gab1 and Gab2 and PI ${ }_{3} \mathrm{~K}$ - mice. $\boldsymbol{F}$, To quantify PKC- $\delta$ translocation, fluorescence intensities were measured at the periphery and the cente , no translocation; $k>1$, translocation to the PM; $k<1$, cytoplasmic localization of PKC- $\delta$. $G$, The facilitation of caps $_{\text {was inhibited }}$ by the PKC $\delta$ inhibitor rottlerin $(n=6)$. $\boldsymbol{H}$, The drop in PWL after HIL-6 injection was significantly attenuated in TRPV $1^{-/-}$mice compared with wt littermates $(n=6)$.

\section{Discussion}

Together, our data suggest that gp130 expressed in the membrane of nociceptive primary afferents is critically required for the development of pathological pain and hyperalgesia in inflammatory conditions as well as in cancer. We observed that deletion of gp130 specifically in sensory nerves alleviates heat hyperalgesia in vivo in models of pathological pain with inflammatory background independently of an anti-inflammatory action or modulation of tumor growth. Our results show that the gp130-Gab1/Gab2-PI ${ }_{3} \mathrm{~K}-$ PKC- $\delta$-TRPV1 pathway in peripheral sensory neurons is a novel molecular pathway linking inflammatory cytokines to pain hypersensitivity.

IL-6 and IL-6-related cytokines share a common signaling receptor subunit gp130 which is ubiquitously expressed in the cellular membrane of all cells types. In contrast to IL-6 the other members of the cytokine group, such as LIF, OSM, CNTF, and 
CT-1, can heterodimerize also with other membrane-bound receptor subunits. The common signaling molecule gp130 is ubiquitously expressed, whereas IL-6R is not (Peters et al., 1998). Therefore, a majority of cell types, including neurons, require the additional presence of soluble IL-6 receptor (Rose-John and Heinrich, 1994; März et al., 1999; Oprée and Kress, 2000).

Application of HIL-6 led to a significant increase in heat responses and a decrease of the activation temperature, which depended on neuronal gp130. The sensitization process occurred at short latency, which suggests the involvement of a fast signaling cascade, rather than the classical cytokine-induced activation of the Janus kinase/signal transducer and activator of transcription pathway, the RAS/mitogen-activated protein kinase pathway and changes in gene expression. The present data favor a gp130 receptor-mediated activation of protein kinases and the consecutive phosphorylation of a heat transducing ion channel, i.e., the heat-transducing vanilloid receptor TRPV1 (Caterina et al., 1997). TRPV1 in its function as a molecular temperature sensor at the cell surface (Julius and Basbaum, 2001) seems to be a likely candidate regulated by IL-6 signaling via PKC-dependent phosphorylation. Inflammatory mediators activating PKC sensitize TRPV1 (Cesare and McNaughton, 1996; Cesare et al., 1999; Premkumar and Ahern, 2000; Sugiura et al., 2002) and PKC inihbitors attenuate the sensitization of heat-activated inward currents by IL-6/gp130 (Obreja et al., 2005). Recent evidence supports the specific involvement of the calcium-independent isoform PKC- $\delta$ in IL-6/gp130 signal transduction (Jain et al., 1999; Novotny-Diermayr et al., 2002). Indeed, we observed translocation of PKC- $\delta$ after stimulating sensory neurons with IL-6 and IL-6-induced increases in $I_{\text {caps }}$ were significantly reduced in the presence of the rottlerin, which inhibits PKC- $\delta$ in neurons (Zhang et al., 2007) but which may have additional effects (Soltoff, 2007). The structure of TRPV1 exhibits several intracellular phosphorylation sites comprising targets for protein kinases like PKA, PKC or PTK (Vellani et al., 2001; Bhave et al., 2002, 2003; Rathee et al., 2002; Jin et al., 2004; Jung et al., 2004; Zhang et al., 2005; Mandadi et al., 2006), and phosphorylation at these sites leaves the channel in a state of increased activity (Numazaki et al., 2002; Mohapatra and Nau, 2003; Mandadi et al., 2006). Additionally, PKC has been shown to regulate exocytosis of TRPV1 channels preformed in cytosolic vesicles into the plasma membrane (Morenilla-Palao et al., 2004) which could cooperate with the sensitization of phosphorylated channel proteins to explain enhanced neuron sensitivity. Our results extend these findings, and we now provide a novel signaling pathway of IL-6/gp130-induced regulation of TRPV1 via activation Gab1/ Gab2, $\mathrm{PI}_{3} \mathrm{~K}$ and $\mathrm{PKC}-\delta$. $\mathrm{PI}_{3} \mathrm{~K}$ has been reported to mediate the early induction of hyperalgesia and also can sensitize TRPV1, possibly through posttranslational modification (Zhuang et al., 2004). It may also indirectly regulate the activity of the channel by upregulating its translation or trafficking (Stein et al., 2006). Previously it has been shown that $\mathrm{PI}_{3} \mathrm{~K}$ rapidly activates intracellular protein kinases, like $\mathrm{PKB} / \mathrm{Akt}$, and some isoforms of PKC like PKC- $\delta$ (Balendran et al., 2000; Plo et al., 2004; Zhuang et al., 2004; Zhu and Oxford, 2007). We demonstrate here that this pathway is activated in sensory neurons. Gp130-mediated activation of PKC- $\delta$ was indicated by a significant translocation to the cell membrane and thus increased proximity to ion channels with sensory function. Precisely this relocation of PKC isoforms has been shown to regulate TRPV1 via phosphorylation and translocation into the plasma membrane, both of which occur at a fast time scale (Morenilla-Palao et al., 2004; Premkumar et al., 2004; Zhang et al., 2005; Mandadi et al., 2006). Apart from the regula- tion of TRPV1, IL-6-dependent activation of PKC- $\delta$ can interact with STAT3, and this enhances the interaction of STAT3 with the gp130 receptor which is the initial step for STAT3 activation by IL-6 (Novotny-Diermayr et al., 2002). In hematopoietic stem cells, IL-6 regulates expression of membrane-bound and -soluble IL-6R $\alpha$ subunits (Campard et al., 2006). Such effects might also contribute to the IL-6-induced nociceptor sensitization and likely further promote TRPV1 regulation downstream of gp130 activation. IL-6R can exist as a soluble protein (sIL-6R), which binds the ligand IL-6. This soluble complex can bind to gp 130 on cells that lack the membrane-bound IL-6R and initiate signaling. The significance of this so called trans-signaling via sIL-6R is generally accepted and very likely exceeds the significance of the membrane-bound IL-6R (for review, see Jones and Rose-John, 2002; Rose-John et al., 2006). Surprisingly, the sIL-R6 was not essentially required in our cellular model, and this is in contrast to previous work in the rat (Obreja et al., 2002a, 2005). It is the general assumption that in many human tissues sIL-6R acts as an agonist in combination with IL-6 resulting in an enhancement of the IL-6 effects, however, sIL-6R may have IL-6-antagonistic effects (for review, see Knüpfer and Preiss, 2008).

In inflammation and cancer, IL- 6 biology is coordinated by membrane-bound and -soluble receptors (Rose-John et al., 2006). Not only in a mouse model of peripheral inflammation alone, but also in a mouse cancer pain model, we observed a major contribution of gp130 expressed on sensory nerves in hyperalgesia, independently of its role in inflammation and tumor growth per se. Both models are characterized by inflammatory changes and activation of immune cells secreting proinflammatory cytokines, such as IL-6 (Constantin et al., 2008). In clinical trials, treatment of patients suffering from rheumatoid arthritis and inflammatory pain with a neutralizing anti-IL-6R antibody was reported to ameliorate symptoms of inflammation as well as the associated pain (Smolen et al., 2008). Our results uncover the significance of gp130 expressed in peripheral pain sensing neurons in the pathophysiology of major clinical pain disorders and suggest its promise as a novel therapeutic target.

\section{References}

Agarwal N, Offermanns S, Kuner R (2004) Conditional gene deletion in primary nociceptive neurons of trigeminal ganglia and dorsal root ganglia. Genesis 38:122-129.

Agarwal N, Pacher P, Tegeder I, Amaya F, Constantin CE, Brenner GJ, Rubino T, Michalski CW, Marsicano G, Monory K, Mackie K, Marian C, Batkai S, Parolaro D, Fischer MJ, Reeh P, Kunos G, Kress M, Lutz B, Woolf CJ, et al. (2007) Cannabinoids mediate analgesia largely via peripheral type 1 cannabinoid receptors in nociceptors. Nat Neurosci 10:870-879.

Balendran A, Hare GR, Kieloch A, Williams MR, Alessi DR (2000) Further evidence that 3-phosphoinositide-dependent protein kinase-1 (PDK1) is required for the stability and phosphorylation of protein kinase $\mathrm{C}$ (PKC) isoforms. FEBS Lett 484:217-223.

Betz UA, Bloch W, van den Broek M, Yoshida K, Taga T, Kishimoto T, Addicks K, Rajewsky K, Müller W (1998) Postnatally induced inactivation of gp130 in mice results in neurological, cardiac, hematopoietic, immunological, hepatic, and pulmonary defects. J Exp Med 188:1955-1965.

Bhave G, Zhu W, Wang H, Brasier DJ, Oxford GS, Gereau RW 4th (2002) cAMP-dependent protein kinase regulates desensitization of the capsaicin receptor (VR1) by direct phosphorylation. Neuron 35:721-731.

Bhave G, Hu HJ, Glauner KS, Zhu W, Wang H, Brasier DJ, Oxford GS, Gereau RW 4th (2003) Protein kinase C phosphorylation sensitizes but does not activate the capsaicin receptor transient receptor potential vanilloid 1 (TRPV1). Proc Natl Acad Sci U S A 100:12480-12485.

Brenn D, Richter F, Schaible HG (2007) Sensitization of unmyelinated sensory fibers of the joint nerve to mechanical stimuli by interleukin- 6 in the 
rat: an inflammatory mechanism of joint pain. Arthritis Rheum 56:351-359.

Campard D, Vasse M, Rose-John S, Poyer F, Lamacz M, Vannier JP (2006) Multilevel regulation of IL-6R by IL-6-sIL-6R fusion protein according to the primitiveness of peripheral blood-derived CD133 + cells. Stem Cells 24:1302-1314.

Carenini S, Mäurer M, Werner A, Blazyca H, Toyka KV, Schmid CD, Raivich G, Martini R (2001) The role of macrophages in demyelinating peripheral nervous system of mice heterozygously deficient in p0. J Cell Biol 152:301-308.

Caterina MJ, Julius D (1999) Sense and specificity: a molecular identity for nociceptors. Curr Opin Neurobiol 9:525-530.

Caterina MJ, Schumacher MA, Tominaga M, Rosen TA, Levine JD, Julius D (1997) The capsaicin receptor: a heat-activated ion channel in the pain pathway. Nature 389:816-824.

Cesare P, McNaughton P (1996) A novel heat-activated current in nociceptive neurons, and its sensitization by bradykinin. Proc Natl Acad Sci U S A 93:15435-15439.

Cesare P, Dekker LV, Sardini A, Parker PJ, McNaughton P (1999) Specific involvement of PKC-epsilon in sensitization of the neuronal response to painful heat. Neuron 23:617-624.

Chalaris A, Rabe B, Paliga K, Lange H, Laskay T, Fielding CA, Jones SA, Rose-John S, Scheller J (2007) Apoptosis is a natural stimulus of IL6R shedding and contributes to the proinflammatory transsignaling function of neutrophils. Blood 110:1748-1755.

Chuang HH, Prescott ED, Kong H, Shields S, Jordt SE, Basbaum AI, Chao MV, Julius D (2001) Bradykinin and nerve growth factor release the capsaicin receptor from PtdIns(4,5)P2-mediated inhibition. Nature 411:957-962.

Constantin CE, Mair N, Sailer CA, Andratsch M, Xu ZZ, Blumer MJ, Scherbakov N, Davis JB, Bluethmann H, Ji RR, Kress M (2008) Endogenous necrosis factor alpha (TNFalpha) requires TNF receptor type 2 to generate heat hyperalgesia in a mouse cancer model. J Neurosci 28:5072-5081.

Davis JB, Gray J, Gunthorpe MJ, Hatcher JP, Davey PT, Overend P, Harries MH, Latcham J, Clapham C, Atkinson K, Hughes SA, Rance K, Grau E, Harper AJ, Pugh PL, Rogers DC, Bingham S, Randall A, Sheardown SA (2000) Vanilloid receptor-1 is essential for inflammatory thermal hyperalgesia. Nature 405:183-187.

DeLeo JA, Colburn RW, Nichols M, Malhotra A (1996) Interleukin-6mediated hyperalgesia/allodynia and incrased spinal IL-6 expression in a rat mononeuropathy model. J Interferon Cytokine Res 16:695-700.

Dittert I, Vlachová V, Knotková H, Vitásková Z, Vyklicky L, Kress M, Reeh PW (1998) A technique for fast application of heated solutions of different composition to cultured neurones. J Neurosci Methods 82:195-201.

Ferreira SH, Lorenzetti BB, Poole S (1993) Bradykinin initiates cytokinemediated inflammatory hyperalgesia. Br J Pharmacol 110:1227-1231.

Fischer M, Goldschmitt J, Peschel C, Brakenhoff JP, Kallen KJ, Wollmer A, Grötzinger J, Rose-John S (1997) A bioactive designer cytokine for human haematopoietic progenitor cell expansion. Nat Biotechnol 15:142-145.

Forster C, Handwerker HO (1990) Automatic classification and analysis of microneurographic spike data using a PC/AT. J Neurosci Methods 31:109-118.

Gardiner NJ, Cafferty WB, Slack SE, Thompson SW (2002) Expression of gp130 and leukaemia inhibitory factor receptor subunits in adult rat sensory neurones: regulation by nerve injury. J Neurochem 83:100-109.

Gschwendt M, Müller HJ, Kielbassa K, Zang R, Kittstein W, Rincke G, Marks F (1994) Rottlerin, a novel proein kinase inhibitor. Biochem Biophys Res Commun 199:93-98.

Hargreaves K, Dubner R, Brown F, Flores C, Joris J (1988) A new and sensitive method for measuring thermal nociception in cutaneous hyperalgesia. Pain 32:77-88.

Heinrich PC, Behrmann I, Haan S, Hermanns HM, Müller-Newen G, Schaper F (2003) Principles of interleukin (IL)-6-type cytokine signalling and its regulation. Biochem J 374:1-20.

Jain N, Zhang T, Kee WH, Li W, Cao X (1999) Protein kinase C delta associates with and phosphorylates Stat 3 in an interleukin-6-dependent manner. J Biol Chem 274:24392-24400.

Jin X, Morsy N, Winston J, Pasricha PJ, Garrett K, Akbarali HI (2004) Modulation of TRPV1 by nonreceptor tyrosine kinase, c-Src kinase. Am J Physiol Cell Physiol 287:C558-C563.

Jones SA, Rose-John S (2002) The role of soluble receptors in cytokine bi- ology: the agonistic properties of the sIL-6R/IL-6 complex. Biochim Biophys Acta 1592:251-263.

Julius D, Basbaum AI (2001) Molecular mechanisms of nociception. Nature 413:203-210.

Jung J, Shin JS, Lee SY, Hwang SW, Koo J, Cho H, Oh U (2004) Phosphorylation of vanilloid receptor 1 by $\mathrm{Ca} 2+/$ calmodulin-dependent kinase II regulates its vanilloid binding. J Biol Chem 279:7048-7054.

Kawasaki K, Gao YH, Yokose S, Kaji Y, Nakamura T, Suda T, Yoshida K, Taga T, Kishimoto T, Kataoka H, Yuasa T, Norimatsu H, Yamaguchi A (1997) Osteoclasts are present in gp130-deficient mice. Endocrinology 138:49594965.

Kawasaki Y, Zhang L, Cheng JK, Ji RR (2008) Cytokine mechanisms of central sensitization: distinct and overlapping role of interleukin-1beta, interleukin-6, and tumor necrosis factor-alpha in regulating synaptic and neuronal activity in the superficial spinal cord. J Neurosci 28:5189-5194.

Kiefer R, Kieseier BC, Stoll G, Hartung HP (2001) The role of macrophages in immune-mediated damage to the peripheral nervous system. Prog Neurobiol 64:109-127.

Knüpfer H, Preiss R (2008) sIL-6R: more than an agonist. Immunol Cell Biol 86:87-91.

Koltzenburg M, Stucky CL, Lewin GR (1997) Receptive properties of mouse sensory neurons innervating hairy skin. J Neurophysiol 78:1841-1850.

Kress M, Koltzenburg M, Reeh PW, Handwerker HO (1992) Responsiveness and functional attributes of electrically localized terminals of cutaneous C-fibers in vivo and in vitro. J Neurophysiol 68:581-595.

Liu CJ, Priest BT, Bugianesi RM, Dulski PM, Felix JP, Dick IE, Brochu RM, Knaus HG, Middleton RE, Kaczorowski GJ, Slaughter RS, Garcia ML, Köhler MG (2006) A high-capacity membrane potential FRET-based assay for NaV1.8 channels. Assay Drug Dev Technol 4:37-48.

Mandadi S, Tominaga T, Numazaki M, Murayama N, Saito N, Armati PJ, Roufogalis BD, Tominaga M (2006) Increased sensitivity of desensitized TRPV1 by PMA occurs through PKCepsilon-mediated phosphorylation at S800. Pain 123:106-116.

März P, Otten U, Rose-John S (1999) Neural activities of IL-6-type cytokines often depend on soluble cytokine receptors. Eur J Neurosci 11:2995-3004.

Minke B, Cook B (2002) TRP channels proteins and signal transduction. Physiol Rev 82:429-472.

Mohapatra DP, Nau C (2003) Desensitization of capsaicin-activated currents in the Vanilloid receptor TRPV1 is decreased by the cyclic AMPdependent protein kinase pathway. J Biol Chem 278:50080-50090.

Montell C (2005) The TRP superfamily of cation channels. Sci STKE 90:re3.

Morenilla-Palao C, Planells-Cases R, García-Sanz N, Ferrer-Montiel A (2004) Regulated exocytosis contributes to protein kinase C potentiation of vanilloid receptor activity. J Biol Chem 279:25665-25672.

Murphy PG, Ramer MS, Borthwick L, Gauldie J, Richardson PM, Bisby MA (1999) Endogenous interleukin-6 contributes to hypersensitivity to cutaneous stimuli and changes in neuropeptides asociated with chronic nerve constriction in mice. Eur J Neurosci 11:2243-2253.

Nishida K, Yoshida Y, Itoh M, Fukada T, Ohtani T, Shirogane T, Atsumi T, Takahashi-Tezuka M, Ishihara K, Hibi M, Hirano T (1999) Gab-family adapter proteins act downstream of cytokine and growth factor receptors and T- and B-cell antigen receptors. Blood 93:1809-1816.

Novotny-Diermayr V, Zhang T, Gu L, Cao X (2002) Protein kinase C delta associates with the interleukin-6 receptor subunit glycoprotein (gp) 130 via Stat3 and enhances Stat3-gp130 interaction. J Biol Chem 277:49134-49142.

Numazaki M, Tominaga T, Toyooka H, Tominaga M (2002) Direct phosphorylation of capsaicin receptor VR1 by protein kinase Cepsilon and identification of two target serine residues. J Biol Chem 277:13375-13378.

Obreja O, Schmelz M, Poole S, Kress M (2002a) Interleukin-6 in combination with its soluble IL-6 receptor sensitises rat skin nociceptors to heat, in vivo. Pain 96:57-62.

Obreja O, Rathee PK, Lips KS, Distler C, Kress M (2002b) IL-1 $\beta$ potentiates heat-activated currents in rat sensory neurons: involvement of IL-1RI, tyrosine kinase and protein kinase C. FASEB J 16:1497-1503.

Obreja O, Biasio W, Andratsch M, Lips KS, Rathee PK, Ludwig A, Rose-John S, Kress M (2005) Fast modulation of heat-activated ionic current by proinflammatory interleukin 6 in rat sensory neurons. Brain 128:1634-1641.

Oka T, Oka K, Hosoi M, Hori T (1995) Intracerebroventricular injection of 
interleukin-6 induces thermal hyperalgesia in rats. Brain Res 692:123-128.

Oprée A, Kress M (2000) Involvement of the proinflammatory cytokines tumor necrosis factor- $\alpha$, IL- $1 \beta$ and IL- 6 but not IL- 8 in the development of heat hyperalgesia: effects on heat-evoked calcitonin gene-related peptide release from rat skin. J Neurosci 20:6289-6293.

Peters M, Müller AM, Rose-John S (1998) Interleukin-6 and soluble interleukin-6 receptor: direct stimulation of gp130 and hematopoiesis. Blood 92:3495-3504.

Plo I, Bono F, Bezombes C, Alam A, Bruno A, Laurent G (2004) Nerve growth factor-induced protein kinase $\mathrm{C}$ stimulation contributes to TrkAdependent inhibition of p75 neurotrophin receptor sphingolipid signaling. J Neurosci Res 77:465-474.

Poole S, Cunha FQ, Selkirk S, Lorenzetti BB, Ferreira SH (1995) Cytokinemediated inflammatory hyperalgesia limited by interleukin-10. Br J Pharmacol 115:684-688.

Premkumar LS, Ahern GP (2000) Induction of vanilloid receptor channel activity by protein kinase C. Nature 408:985-990.

Premkumar LS, Qi ZH, Van Buren J, Raisinghani M (2004) Enhancement of potency and efficacy of NADA by PKC-mediated phosporylation of vanilloid receptor. J Neurophysiol 91:1442-1449.

Rathee PK, Distler C, Obreja O, Neuhuber W, Wang GK, Wang SY, Nau C, Kress M (2002) PKA/AKAP/VR-1 module: a common link of Gsmediated signaling to thermal hyperalgesia. J Neurosci 22:4740-4745.

Reeh PW (1986) Sensory receptors in mammalian skin in an in vitro preparation. Neurosci Lett 66:141-146.

Rose-John S, Heinrich PC (1994) Soluble receptors for cytokines and growth factors: generation and biological function. Biochem J 300: 281-290.

Rose-John S, Scheller J, Elson G, Jones SA (2006) Interleukin-6 biology is coordinated by membrane-bound and soluble receptors: role in inflammation and cancer. J Leukoc Biol 80:227-236.

Sambrook J, Russell DW (2001) Molecular cloning. New York: Cold Spring Harbor Laboratory.

Schäfer KH, Mestres P, März P, Rose-John S (1999) The IL-6/sIL-6R fusion protein hyper-IL-6 promotes neurite outgrowth and neuron survival in cultured enteric neurons. J Interferon Cytokine Res 19:527-532.

Scheller J, Schuster B, Hölscher C, Yoshimoto T, Rose-John S (2005) No inhibition of IL-27 signaling by soluble gp130. Biochem Biophys Res Commun 326:724-728.

Scott K, Zuker C (1998) TRP, TRPL and trouble in photoreceptor cells. Curr Opin Neurobiol 8:383-388.

Smith PC, Hobisch A, Lin DL, Culig Z, Keller ET (2001) Interleukin-6 and prostate cancer progression. Cytokine Growth Factor Rev 12:33-40.
Smolen JS, Beaulieu A, Rubbert-Roth A, Ramos-Remus C, Rovensky J, Alecock E, Woodworth T, Alten R, OPTION investigators (2008) Effect of interleukin-6 receptor inhibition with tocilizumab in patients with rheumatoid arthritis (OPTION study): a double-blind, placebocontrolled, randomised trial. Lancet 371:987-997.

Soltoff SP (2007) Rottlerin: an inappropirate and ineffective inhibitor of PKC $\delta$. Trends Pharmacol Sci 28:453-458.

Stein AT, Ufret-Vincenty CA, Hua L, Santana LF, Gordon SE (2006) Phosphoinosite 3-kinase binds to TRPV1 and mediates NGF-stimulated TRPV1 trafficking to the plasma membrane. J Gen Physiol 128:509-522.

Sugiura T, Tominaga M, Katsuya H, Mizumura K (2002) Bradykinin lowers the threshold temperature for heat activation of vanilloid receptor 1 . J Neurophysiol 88:544-548.

Taga T, Hibi M, Hirata Y, Yamasaki K, Yasukawa K, Matsuda T, Hirano T, Kishimoto T (1989) Interleukin-6 triggers the association of its receptor with a possible signal transducer, gp130. Cell 58:573-581.

Vellani V, Mapplebeck S, Moriondo A, Davis JB, McNaughton PA (2001) Protein kinase $\mathrm{C}$ activation potentiates gating of the vanilloid receptor VR-1 by capsaicin, protons, heat and anandamide. J Physiol 534:813-825.

Xu XJ, Hao JX, Andell-Jonsson S, Poli V, Bartfai T, Wiesenfeld-Hallin Z (1997) Nociceptive responses in interleukin-6-deficient mice to peripheral inflammation and peripheral nerve section. Cytokine 9:1028-1033.

Yoshida K, Taga T, Saito M, Suematsu S, Kumanogoh A, Tanaka T, Fujiwara H, Hirata M, Yamagami T, Nakahata T, Hirabayashi T, Yoneda Y, Tanaka K, Wang WZ, Mori C, Shiota K, Yoshida N, Kishimoto T (1996) Targeted disruption of gp130, a common signal transducer for the interleukin 6 family of cytokines, leads to myocardial and hematological disorders. Proc Natl Acad Sci U S A 93:407-411.

Zhang D, Kanthasamy A, Yang Y, Anantharam V, Kanthasamy A (2007) Protein kinase $\mathrm{C}$ delta negatively regulates tyrosine hydroxylase activity and dopamine synthesis by enhancing protein phosphatase-2A activity in dopaminergic neurons. J Neurosci 27:5349-5362.

Zhang X, Huang J, McNaughton PA (2005) NGF rapidly increases membrane expression of TRPV1 heat-gated ion channels. EMBO J 24:42114223.

Zhu W, Oxford GS (2007) Phosphoinositide-3-kinase and mitogen activated protein kinase signaling pathways mediate acute NGF sensitization of TRPV1. Mol Cell Neurosci 34:689-700.

Zhuang ZY, Xu H, Clapham DE, Ji RR (2004) Phosphatidylinositol 3-kinase activates ERK in primary sensory neurons and mediates inflammatory heat hyperalgesia through TRPV1 sensitization. J Neurosci 24:83008309. 